\title{
Audit of Otological Diseases amongst Elderly in Nigeria
}

\section{Auditoria da Otological Doenças entre Idosos na Nigéria}

\author{
Aremu Shuaib Kayode*, Biodun Sulymam Alabi*, Segun-Busari Segun*, Stephen A. Ogab**. \\ * FWACS. Consultant ENT. \\ *** MBBS. Registrar. \\ Institution: Unilorin Teaching Hospital. \\ Ilorin - Nigeria. \\ Mail Address: P.O.BOX 685, Ilorin - Nigeria - Telephone: +2348033583842 - E-mail: shuaib.aremu@gmail.com \\ Article received March 26, 2010. Article approved April 12, 2010.
}

\section{SUMMARY}

Introduction:

Aging process is associated with degeneration in different part of the body There is scarcity of literature on the otological diseases in the elderly black African especially Nigerian which is the largest African nation. Thus this study is done with the aim of highlighting the pattern of otological diseases in elderly for careful cost-effective health care plans and to make the aging period more fulfilling and tolerable to the elderly. It is therefore hope that the information will go a long way to assist other African countries as well.

Method: The study is a ten year hospital-based retrospective study between January, 1999 and December, 2008 at the ENT Department of Unilorin Teaching Hospital Ilorin. All patients aged 65 years and above with otological complaints were included in the study.

Results:

A total of 740 Elderly patients were included in the study. The male to female sex ratio was 1.5:1.0.Petty Traders accounted for 300 (40.5\%) of cases; 87 (11.8\%) were Farmers; 250 (33.8\%) were Retired Civil Servants; 68 (9.2\%) were Unskilled Laborers and 35 (4.7\%) were full-time Housewives. Aural wax impaction was the commonest otological disease found, accounting for 360 (48.7\%) of cases, Hearing loss (presbyacusis),158 (21.4\%); Tinnitus, 78 (10.5\%) and Otomycosis,64 (8.5\%). Other conditions were CSOM,34 (4.6\%); Foreign body Impaction,32 (4.3\%); Vertigo,10 (1.4\%) and Aural Tumours,5 (0.6\%).

Conclusion: Aural wax impaction was the commonest disease found, thus it is important to always do full audiologic evaluation after aural syringing to rule out other conditions such as presbyacusis and aural tumours in elderly. Continuing medical education is recommended for the general practitioners for early recognition and referral.

Keywords: ear diseases, aged, otitis media, suppurative.

\section{RESUMO}

Introdução:

Método:

Resultados:

Conclusão:

Palavras-chaves:
O processo de envelhecimento está associado com a degeneração em parte diferente do corpo, há escassez de literatura sobre as doenças otológicas no Africano idosos negros, especialmente da Nigéria, que é o maior país Africano. Assim, este estudo é feito com o objetivo de realçar o padrão de doenças otológicas em idosos cuidado para planos de cuidados de saúde custo-benefício e fazer o período de envelhecimento mais satisfatório e aceitável para os idosos. É, portanto, esperamos que a informação irá percorrer um longo caminho para ajudar outros países Africano também.

O estudo é uma criança de dez anos de estudo retrospectivo de base hospitalar no período de janeiro de 1999 e dezembro de 2008, no Departamento de Otorrinolaringologia do Hospital Unilorin Ilorin. Todos os pacientes com idade acima de 65 anos e com queixas otológicas foram incluídos no estudo. Um total de 740 pacientes idosos foram incluídos no estudo. O macho à relação de sexo feminino foi de 1,5:1,0. Petty Traders contabilizados 300 (40,5\%) dos casos, 87 (11,8\%) eram agricultores, 250 $(33,8 \%)$ eram aposentados da Função Pública, 68 (9,2\%) eram trabalhadores não qualificados e 35 $(4,7 \%)$ eram donas de casa em tempo integral. Aural impactação da cera foi a doença mais comum encontrada otológica, sendo responsável por 360 (48,7\%) dos casos, perda auditiva (presbiacusia), 158 (21,4\%), zumbido, 78 (10,5\%) e otomicose, 64 (8,5\%). Outras condições foram OMCS, 34 (4,6\%); Inclusão de corpo estranho, 32 (4,3\%); Vertigo, 10 (1,4\%) e Aural tumores, cinco (0,6\%).

Impactação da cera Aural foi a doença mais comum encontrada, por isso é importante sempre fazer a avaliação audiológica completa após syringing fonética para descartar outras condições, tais como presbiacusia e tumores auditiva em idosos. Educação médica continuada é recomendado para os médicos de clínica geral para a identificação precoce e encaminhamento.

otopatias, idoso, otite média supurativa. 


\section{INTRODUCTION}

The aging process in human affects all the organs of the body, including the ear (the external, the middle and the inner ear). For this reason the various parts are usually diseased should the individual live long enough. As most of these diseases are usually not life threatening, little or no attention is paid to them and hence, there is scarcity of information about the pattern of otological diseases in elderly Nigerians.

We live in an aging world with the population of older people rising steadily. While the impact of the increase in numbers has been well appreciated in the developed countries for a long time, it is only recently that geriatric population has been fully acknowledged as category of people that need special attention in Nigeria.

The ear which is the sense organ of hearing consists of the outer, middle and inner part. Each of which plays an in important role in hearing (1). With increasing age, there is degeneration of the tissues which makes the individual more prone to diseases of the ear such as presbyacusis, impacted wax, chronic suppurative otitis media etc $(1,2,3)$.

There is also the relation between the hearing of an individual with diseases of other systems $(4,5,6,7,8)$. The age of 65 years, according to WHO, is regarded as the margin between the older people and middle age and in Nigeria about 5\% (12.3 million) of the population falls in this category (9). It is estimated that $4.7 \%$ of these population isfound in sub-Saharan Africa while in developed countries people of this age group constitute $11 \%-18 \%$ of the population (10).

ZWAARDEMAKER in 1891 is documented the reduction of high-frequency hearing associated with increased age. His interest, however, involved determining the highest frequency heard at various ages rather than acuity at a given frequency $(3,11)$. Bunch (12) in 1929 documented not only the aging pattern - Presbycusis - but also the fact that females tend to retain hearing acuity more than their age-matched males. Many researchers have examined the prevalence of hearing loss in older populations (13). Therefore, emphasis on public health, which is currently on maternal and child health, is likely to extend to the health problems of old people (13).

The aging process and the last stage of life is satisfying for some and disappointing for others (10). Unfortunately little information is available in Nigeria and in many developing countries about ear disease pattern in the older population. Studies on ear diseases in this age group are almost nonexistent (14). There is need, therefore, to study the pattern of ear diseases among older people in developing countries so as to be able to plan a costeffective program for the control and prevention of such diseases, which can have significant adverse effects on quality of life (14). As the Life expectancy in Nigeria was 36 years in 1960, but now it is 51 years for males and 53 years for females $(15,16)$.

\section{METHOD}

This hospital-based retrospective study was carried out between January, 1999 and December, 2008 at University of Ilorin Teaching Hospital which is located in Ilorin, the Kwara state capital in the middle belt zone of Nigeria. The hospital sub-serves about eight states namely Kwara, Kogi, Niger, Oyo, Osun, Ekiti, Lagos and part of Kebbi states. Department of Ear, Nose and Throat is one of the hospital departments that have services covering the above mentioned zones in terms of patient coverage.

The case notes of patients aged 65 years and above who presented with otological diseases to the ENT surgeons were enrolled into the study. The age of 65 years was selected as the dividing line between middle and elderly age according to the WHO current age classification. Excluded from the study were: those below 65 years of age; those with no otological complaints and those with incomplete records of data. The information retrieved included demographic data: age, sex, occupation, and tribe; history of otological disease; duration of complaint and physical examination including otoscopic findings were noted.

Results of ear swab for bacteriology and fungal studies, pure tone audiometry and tympanometry were recorded from their case notes.

\section{RESULTS}

A total of 760 patients aged 65 years and above presented during this study period with otological complaints. However, twenty of them were excluded because of inadequate records of data. The remaining 740 patients formed the data base of the study.

Four hundred and forty-four (60\%) patients were male with male to female sex ration of 1.5:1 (Table 1 ). The majority (54.6\%) of the subjects fall within the age range of $65-75$ years, while the least $(3.7 \%)$ fall in $>94$ years (Table 2). With regards to occupation, three hundred (40.5\%) were petty-traders, 87 (11.8\%) were farmers, 250 (33.8\%) were retired civil-servants.68 (9.2\%) were unskilled laborers and 35 (4.7\%) were full-time housewives (Table 
Table I. Sex distribution.

\begin{tabular}{lcc}
\hline Sex & Frequeency & Percentage(\%) \\
\hline Male & 444 & 60 \\
Female & 296 & 40 \\
\hline Total & 740 & 100 \\
\hline
\end{tabular}

$M: F, \mid .5: 1$

Table 2. Age distribution.

\begin{tabular}{lc}
\hline Age Range & Percentage $(\%)$ \\
\hline $65-74$ & 54.6 \\
$75-84$ & 35.4 \\
$85-94$ & 6.3 \\
$>94$ & 3.7 \\
\hline Total & 100 \\
\hline
\end{tabular}

3). All the studied subjects were Nigerians cutting across all the tribes. However, majority, 629 (85\%) were Yorubas. Other tribes include Hausa, Fulani, Nupe and Ibo.

The commonest otological disease condition found was aural wax impaction, 360 (48.7\%) which was followed by age-related hearing loss, presbyacusis, $158(21.4 \%)$ and tinnitus, 78 (10.5\%).

Of the infective conditions, otomycosis ranked first, representing, 63 (8.5\%) of all subjects studied, 15 (23.8\%) of patients with otomycosis had diabetes mellitus. This was followed by chronic suppurative otitis media (CSOM), 34 (4.6\%). CSOM was unilateral in 598 (80.8\%) and bilateral in 142 (19.2\%). Foreign body impaction accounted for 32 (4.3\%); Vertigo, 10 (1.4\%) and Aural tumours were found in $5(0.6 \%)$ of cases (Table 4).

\section{DISCUSSION}

Otological disease and hearing loss associated with aging is common among older people (17). The male/ female ratio found in this study is 1.5:1.0. There are a number of patho-physiological processes underlying agerelated changes to functional components in the inner ear (17).

Aging in US this is the commonest cause of hearing impairment among the older people (17) compared to our environment where aural wax impaction was the commonest problem encountered among the elderly. In UK the incidence ranges between $30 \%$ and $65 \%(14,18,19)$. In our study an incidence of $48.7 \%$ was found which is high compared to $14.4 \%$ found in the population studies done in Thailand (20). The difference in the incidence may
Table 3. Occupational distribution.

\begin{tabular}{ll}
\hline 1. Petty Traders & $-300(40.50 \%)(9.20 \%)$ \\
2. Farmers & $-87(11.80 \%)$ \\
3. Retired Civil-Servants & $-250(33.8 \%)$ \\
4. Unskilled Laborers & -68 \\
5. Full-time Housewives & $-35(4.7 \%)$ \\
\hline
\end{tabular}

Table 4. Pattern of otological diseases.

\begin{tabular}{ll}
\hline 1. Aural wax Impaction & -360 \\
2. Presbyacusis & -158 \\
3. Tinnitus & -78 \\
4. Otomycosis & -63 \\
5. CSOM & -34 \\
6. Foreign Body & -32 \\
7. Vertigo & -10 \\
8. Aural tumours & -5 \\
\hline
\end{tabular}

support the racial difference in wax component between the races which may encourage impaction (21). Unilateral account for $65.3 \%$ while it was bilateral in $34.7 \%$ of cases. This was against other studies in East and Central African Journal of Surgery http://www.bioline.org.br/js99 where bilateral was more common than unilateral (22). Impacted cerumen can cause a variety of symptoms (23) including itching, pain, hearing loss, tinnitus, dizziness and increased infection risk (18).

Furthermore, untreated impacted wax can lead to hearing loss, social withdrawal, poor work function and even mild paranoia $(12,14,27)$. Some patients with impacted wax present with perforated eardrums (24) which is usually self-induced. It is a reversible, frequently overlooked cause of conductive hearing loss in older people (25-28). Risk factors for cerumen impaction include anatomical nature of ear canal, ear canal hair, self repeated ear cleaning, hearing aids, and bony growths such as osteoma (28). Removal of aural wax significantly improves hearing ability by about $5 \mathrm{~dB}(21)$ but the cerumen removal must be carefully done by qualified personnel, because removal by an inexperienced person can cause damage to the wall of the external auditory meatus, traumatic perforation of the tympanic membrane, and/or otitis media (26). High level of hearing loss increases the burden of disability on society (28).

Age related hearing loss, presbyacusis, closely followed aural wax impaction; accounting for $21.4 \%$ of cases. This is unlike some studies in which CSOM was the second most common otological disease in elderly.

Numerous epidemiological studies indicate that threshold of hearing and the prevalence of hearing disability increase markedly with age $(29,30)$. 
Since the nineteenth century when ZwAARDENMAKER (12) introduced the term presbyacusis to denote the deterioration of hearing with age, many have described the abnormalities in auditory pathway attributed to the aging process.

Of the infectious diseases, Otomycosis accounted for the majority (8.5\%). (23.8\%) of this had Diabetes Mellitus. This was closely followed by Otitis media, but most had developed CSOM (4.6\%) at presentation. Poor socioeconomic circumstances, obvious in our study population lead to increased prevalence of CSOM compared to that in more affluent population groups (28). Most of them presented late because they have ardent belief in home remedies, traditional medicine, and spiritual cures $(11,28)$. Older people feel too frail to use available public transportation, and find it difficult to stand in line for long periods to see a doctor in a busy hospital (33).

Five $(0.6 \%)$ cases of aural tumours were found during the study period. Majority 4 (80\%) were benign tumours. However 1 (20\%) case of malignant tumour, squamous cell carcinoma, was found.Squamous cell carcinoma is the commonest malignant tumour of the EAC, most of the rest are glandular in origin e.g adenocystic carcinomas, ceruminous adenocarcinomas, e.t.c. Most showed no specific symptoms and such presented late with treatment results being disappointing.

\section{CONCLUSION}

Aural wax impaction was the commonest disease found, thus it is important to always do full audiologic evaluation after aural syringing to rule out other conditions such as presbyacusis and aural tumours. Continuing medical education is recommended for the general practitioners for early recognition and referral. Age-adjusted policies and Programmes that encourage workplace flexibility, lifelong learning and healthy lifestyles, especially during transitional periods should be put in place.

\section{Bibliographical ReferenCES}

1. Basic anatomy of the ear and the physiology of hearing: $7^{\text {th }}$ Ed. Scott-Brown Otolaryngology Head and Neck Surgery, 2008, vol. 3 part 19, page 3103-3298.

2. Diseases of the ear and their clinical presentation: $7^{\text {th }} \mathrm{Ed}$. Scott-Brown Otolaryngology Head and Neck Surgery, 2008, vol.3 part 19, page 3311-3526.

3. Age-related Sensorineural Hearing Impairment: $7^{\text {th }}$ Ed.
Scott-Brown Otolaryngology Head and Neck Surgery, 2008, vol.3 part 19, page 3539.

4. Lichtenstein MJ, Hazuda HP. Cross-cultural adaptation of the Hearing Handicap for the Elderly (HHIE-S) for use with Spanish speaking Mexican Americans. J Am Geriatr Soc. 1998, 46:492-8.

5. Fino MS, Bess FH, Lichtenstein MJ, Logan SA. Factors differentiating elderly hearing aid users and non-users. Hearing Instruments. 1992, 43:8-10.

6. Gates GA, CobbJL. DAgostino RB, Wolf PA. The relation of hearing in the elderly to the presence of cardiovascular disease and cardiovascular risk factor. Arch Otolaryngol Head Neck Surg. 1993, 119:156-61.

7. Zoreh Davanipour, Nicole M. Lu, Michael Lichtenstein, and Kyriakos S. Markides Hearing Problems in Mexican American Elderly. The Am J Otol. 2000, 21:168-172.

8. Jane A. Enrietto, MA, Kathleen M. Jacobson, BA, and Robert Vi? Baloh, MD*4Aging Effects on Auditory and Vestibular Responses. Am J Otolaryngol. 2009, 20(6):371-378.

9. Afolabi OA et al. Pattern of Ear Diseases Among Older People East and Central African Journal of Surgery http:// www.bioline.org.br/js96

10. Senator Iroegbu, Nigeria: Caring for the Aged . . . Task Before Nigeria. This Day Nigeria, June 4, 2007.

11. Victoria A, Velkoff, Paul R Kowal. International Population Reports on Population Aging in Sub-Saharan Africa: Demographic Dimensions, 2006, Issued June 2007.

12. Zwaardemaker, H. (1891). Der verlust an hohen toenen mit zuhenmender alter: ein neues gesetz [the loss of high tones in advanced age; a new law]. Archive furohrenhkunde, 32:52-56.

13. Bunch CC (1929). Age variations in auditory acuity. Archives of otolaryngology, 9; 625-636. East and Central African Journal of Surgery, http://www.bioline.org.br/js100

14. Ologe FE, Segun-Busari S, Afolabi OA, Abdulraheem IS. Pattern of Hearing Loss Among the Elderly .Journal of Gerontology: Medical Science. 2005, 60A(3):404-406.

15. Baiyewu O, Bella AF, Adeyemi JD, Bamigboye EA, Jegede RO. Health problems and sociodemographic findings in elderly Nigerians. Afr J Med Med Sci. 1997, 26:1317.

16. Ogungbo BI, Gregson B, Mendelow AD, Walker R. 
Cerebrovascular disease in Nigeria: what do we know and what do we need to know? Trop Doct. 2003, 33:25-30.

17. Guest JF, Greener MJ, Robinson AI, Smith AF. Impacted cerumen: composition, production, epidemiology and management. QJM. 2004, 97:477-88.

18. Aung T, Mulley GP. Removal of earwax. BMJ. 2002, 325:27.

19. Bunnag C, Prasansuk S, Nakorn AN et al Ear diseases and hearing in the thai elderly population. A one year followup study. J Med Assoc Thai. 2002, 85(5):532-9.

20. Richlee FamiLee Life Racial Differences in ear wax the inside and Outside of Academia at Jan 302006 http://blog.lib.umn.edu/richlee/thought

21. Lewis-Cullinan C, Janken JK. Effect of cerumen removal on the hearing ability of geriatric patients. J Adv Nuls. 1990, 15:594-600.

22. Karlsmose B, Lauritzen T, Engberg M, et al. A randomised controlled trial of screening for adult hearing loss during preventive health checks. Br J Gen Pract. 2001, 51:3515.
23. Burkhart CN, Kruge MA, Burkhart CG, et al. Cerumen composition by flash pyrolysis-gas chromatography/mass spectrometry. Otol Neurotol. 2001, 22:715-22.

24. Nwabuisi C, Ologe FE. The fungal profile of otomycosis patients in Ilorin, Nigeria. Niger J Med. 2001, 10(3):124-126.

25. Nwabuisi C, Ologe FE. Pathogenic agents of chronic suppurative otitis media in IIorin, Nigeria. East Afr Med J. 2002, 79:202-205.

26. Meador JA. Cerumen impaction in the elderly. J Gerontol Nuls. 1995, 21:43-45.

27. Lasisi OA, Sulaiman OA and Afolabi OA Socio-economic status and hearing loss in chronic suppurative otitis media in Nigeria. Annals of Tropical Paediatrics, 2007, 27:291-296.

28. Sharp JF, Wilson JA, Ross L, et al. Ear wax removal: A survey of current practice. Br Med J. 1990, 301:1251-3.

29. Hinchcliffe R. The threshold of hearing as a function of age. Acustica. 1959, 9:303-308.

30. Corso J. Age and sex differences in pure tone thresholds.Arch.Otolaringol. 1963, 77:385-405. 